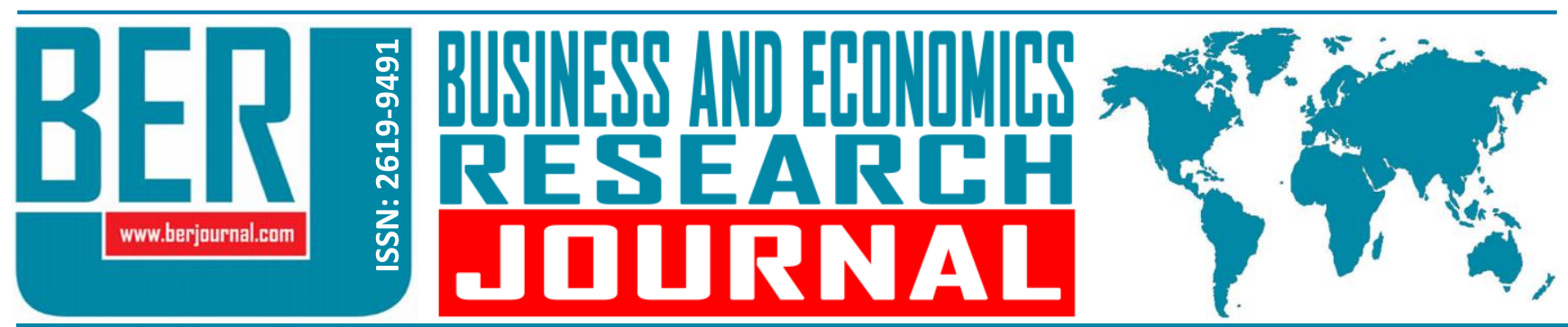

Business and Economics Research Journal Vol. 11, No. 1, 2020, pp. 187-199 doi: 10.20409/berj.2020.244

\section{Küçük ve Mikro İşletmeler İçin Finansal Raporlama Standardı Taslağı'nın BOBİ FRS ve Vergi Uygulamalarımız İle Karşılaştırılması ve Genel Değerlendirme}

\section{Umit Gucenme Gencoglu}

Öz: Ülkemizde 1994 yılından bu yana yasal kayıtlar için kullanılan Muhasebe Sistemi Uygulama Genel Tebliğleri (MSUGT) kapsamındaki düzenlemeler ve vergi kanunlarımızdaki değerleme ölçüleri ile hazırlanan finansal tablolar, Uluslararası Finansal Raporlama Standartları'nın (TFRS) gereklerini karşılamamaktadır. Bağımsız muhasebe denetimine tabi olan Kamu Yararını ilgilendiren Kuruluşlar tarafından TFRS'ler, diğerleri ise TFRS'ler ile uyumlu olan Büyük ve Orta Boy İ̧̧letmeler İçin Finansal Raporlama Standardı'na göre raporlama yapmaktadır. Denetim kapsamı dışındaki işletmelerin de bu standartlar ile uyumlu ancak MSUGT ve vergi düzenlemelerimize daha yakın bir raporlama çerçevesini kullanması, böylece denetim kapsamı dışındaki işletmelerin de bilgi amaçı finansal raporlama yapması amacıyla Kamu Gözetimi Kurumu tarafından "Küçük ve Mikro Iş̧letmeler İ̧̧in Finansal Raporlama Standardı (KÜMi FRS)" için taslak hazırlanmıştır. Standartlara göre hazırlanan finansal tablolar, vergi matrahının tespiti amacıyla değil, Devlet dışında işletmenin diğer paydaşlarına işletme hakkında gerçeğe uygun, karşılaştırılabilir ve ihtiyaca uygun bilgileri sağlama amacıyla hazırlanmaktadır. Bu tablolardaki bilgiler ile işletme yöneticilerinin ve diğer paydaşlarının rasyonel kararlar almasının sağlanması, böylece işletmenin rekabet gücünün artırılması amaçlanmaktadır. Bu çalışmanın amacı, ülkemizde bilgi amaçı finansal raporlama anlayışının yerleşmesine büyük katkı sağlayacak olan KÜMi FRS'nin, TFRS'lerin daha sade ve ülkemize özgü uygulaması olan BOBi FRS ve vergi uygulamalarımız ile karşılaştırılarak açıklanmasıdır.

\section{Comparison of the Financial Reporting Standard for Small and Micro Businesses with BOBI FRS and Tax Practices in Turkey and General Evaluation}

Anahtar Sözcükler: Küçük ve Mikro İşletmeler İçin Finansal Raporlama Standardı, Finansal Raporlama Standartları, Faydalı Finansal Bilgi

JEL: M40, M48

$\begin{array}{ll}\text { Geliş } & : 25 \text { Ekim } 2019 \\ \text { Düzeltme } & : 18 \text { Aralık } 2019 \\ \text { Kabul } & : 26 \text { Aralık } 2019 \\ & \\ \text { Tür } & : \text { Kuramsal }\end{array}$

Keywords: Financial Reporting Standard for Small and Micro Businesses, Financial Reporting Standards, Useful Financial Information

JEL: M40, M48

Received : 25 October 2019

Revised : 18 December 2019

Accepted : 26 December 2019

Type : Conceptual 


\section{Giriş}

Kamu Gözetimi Muhasebe ve Denetim Standartları Kurumu (KGK) tarafından uygulama kapsamı, Kamu Yararını Illgilendiren Kuruluşlar (KAYiK) ile sınırlandırılmış olan ve ülkemizde 2005 yılından bu yana kullanılan Türkiye Muhasebe Standartları ile KGK tarafından 2017 yılında yayımlanan ve 2018 yılı başından itibaren kullanılan Büyük ve Orta Boy İşletmeler için Finansal Raporlama Standardı (BOBi FRS), bağımsız denetime tabi olan işletmeler tarafından uygulanmak zorundadır. Temel özellikleri aynı esaslara dayanan bu iki raporlama çerçevesi, Kamu Yararını İlgilendiren Kuruluşlar (KAYiK)'ler ile büyük ve orta boy işletmelerin gerçeğe ve intiyaca uygun, karşılaştırılabilir finansal tablolar hazırlamalarını sağlamıştır. Ancak bilanço esasına göre defter tutan ve bağımsız denetime tabi olmayan küçük ve mikro işletmeler, 1994 yılından itibaren yasal kayıtların tutulmasında kullanılan ve denetime tabi olan işletmelerin raporlama çerçevelerinin gereklerini karşılamayan Muhasebe Sistemi Uygulama Genel Tebliği (MSUGT) kapsamındaki Tekdüzen Muhasebe Sistemi'ni kullanmaya devam etmişlerdir (kgk.gov.tr). Ancak MSUGT'lara göre hazırlanan finansal tablolarda Vergi Usul Kanunu'ndaki değerleme ölçüleri esas alındığından bu tablolar, mükelleflerin vergi karşısındaki durumunu göstermek amacıyla kullanılmış, gerçeğe ve ihtiyaca uygun, karşılaştırılabilir bilgi sağlama amacından uzaklaşmıştır

Ülkemizdeki tüm finansal raporlama çerçevelerinin uyumunu sağlamak amacıyla KGK tarafından, Küçük ve Mikro İşletmeler İçin Finansal Raporlama Standardı (KÜMi FRS) Taslağı hazırlanmış ve 12 Temmuz 2019 tarihi itibariyle kamuoyunun görüşüne açılmıştır. TFRS ve BOBi FRS'ye göre uygulanması daha kolay ve daha az maliyetli olan, uluslararası finansal raporlama uygulamalarıyla tutarlı, daha ziyade BOBi FRS ile uyumlu fakat ülkemizdeki vergi uygulamalarına diğerlerinden daha yakın olan ve bilgi için finansal tablo düzenlenmesinde Tekdüzen Muhasebe Sisteminin yerine kullanılması amaçlanan KÜMi FRS ile vergi esaslı muhasebe anlayışından, bilgi esaslı muhasebe anlayışına geçilmesi sağlanacaktır.

Bu çalışmada, KÜMi FRS'nin temel özelliklerinin, vergi uygulamaları için kullanılan MSUGT kapsamındaki Tekdüzen Muhasebe Sistemi ve BOBi FRS ile karşılaştırılarak farkların ortaya konması amaçlanmaktadır.

\section{Küçük ve Mikro İşletmeler İçin Finansal Raporlama Standardı Taslağı'nın Temel Özellikleri}

Sade bir anlatım diliyle kaleme alınmış ve 22 bölümden oluşan, KÜMi FRS ile ülkemiz ekonomisinde yer alan çok sayıdaki küçük ve mikro ölçekteki işletme için gerçeğe ve intiyaca uygun, karşılaştırılabilir finansal tabloların hazırlanmasının sağlanması, halen uygulamacılar için hakim olan vergi için muhasebe anlayışından bilgi için muhasebe anlayışına geçiş için temel oluşturulması amaçlanmaktadır. 01/01/2021 tarihi ve sonrasında başlayan hesap dönemlerinden itibaren uygulamaya konulması planlanan KÜMi FRS'ye göre hazırlanan, gerçeğe ve ihtiyaca uygun bilgi sunan finansal tablolar, işletme yöneticilerinin kararlarına dayanak oluşturacak ve tüm ilgili tarafların, işletmelerin gerçek durumunu doğru değerlendirmelerini ve rasyonel kararlar almalarını sağlayacaktır.

KÜMi FRS ile ilgili düzenlemede, Avrupa Birliği (AB) Direktifinde yer alan ölçütlere ve bağımsız denetime tabi olma ölçütlerine uygun bir şekilde küçük ve mikro işletme tanımı yapılmaktadır. Bir işletmenin küçük işletme sayılabilmesi için $A B$ Direktifine göre aşağıdaki üç ölçütten en az ikisini sağlaması gerekmektedir. Küçük işletme ölçütlerini sağlamayan işletmeler mikro işletme olarak değerlendirilecek olup, mikro işletmelerden bilanço esasına göre defter tutma hadlerini sağlamayan işletmeler bu düzenleme kapsamında yer almayacaktır.

Küçük ve Mikro İşletmeler İçin Finansal Raporlama Standardı'nın hazırlanmasında; AB Direktifi, İngiltere'nin mikro işletmeler açısından yürürlükte olan standardı FRS 105 ve ülkemizde daha önceden uygulanmış muhasebe düzenlemelerinin yanı sıra diğer ülkelerin yerel finansal raporlama çerçevelerinden faydalanılmıştır (kgk.gov.tr).

KÜMi FRS seti yürürlüğe girdiğinde küçük ve mikro işletmeler için ayrı tanımlamaların yapılması planlanmaktadır. Bu kapsamda, aktif toplamı, net satış hasılatı ve çalışan sayısı için belirlenen hadlerden en az ikisini sağlayan işletmeler küçük işletme olarak tanımlanacak ve KÜMi FRS seti uygulama kapsamına 
alınacaktır. Diğer yandan, mikro işletme olarak tanımlanan işletmelerden bilanço esasına göre defter tutma hadlerini sağlayan işletmeler de KÜMi FRS seti uygulama kapsamında yer alacak, sağlamayanlar ise bu düzenleme kapsamı dışında tutulacaktır( Gökçen vd., 2019: 415).

\section{Küçük ve Mikro Ölçekli İşletmeler İçin Finansal Raporlama Standardı Taslağı'nın BOBi FRS ve Vergi Uygulamaları ile Karşılaştırılması}

Bağımsız denetime tabi olan işletmeler tarafından kullanılan TFRS ve BOBi FRS ile karşılaştırıldığında KÜMi FRS, uygulayıcılar açısından daha az maliyetli olacak şekilde tasarlanmıştır. Örneğin; TFRS ve BOBi FRS uygulayan diğer işletmelerden farklı olarak, KÜMi FRS kapsamındaki işletmelerin sadece "Finansal Durum Tablosu" ve "Kâr veya Zarar Tablosu" sunması yeterlidir. BOBi FRS uygulayan büyük işletmeler için zorunlu, orta boy işletmeler için ihtiyari olan konsolide finansal tablo hazırlama, ertelenmiş vergi hesaplama gibi yükümlükler, KÜMi FRS'de yer almamaktadır ve genel itibarıyla maliyet esaslı bir yaklaşım benimsenmiştir.

BOBi FRS'de yer alan "Bölüm 2: Nakit Akış Tablosu", "Bölüm 8: Maden Kaynaklarının Aranması ve Değerlendirilmesi", "Bölüm 10: İştiraklerdeki Yatırımlar", "Bölüm 11: Müşterek Girişimlerdeki Yatırımlar", "Bölüm 24: Ara Dönem Finansal Raporlama", "Bölüm 25: Yüksek Enflasyonlu Ekonomilerde Finansal Raporlama ile Illgili Düzenlemeler", KÜMi FRS'de yer almamaktadır.

BOBi FRS'de "Bölüm 1: Kavramsal Çerçeve ve Finansal Tablolar" içindeki düzenlemeler, KÜMi FRS'de, "Bölüm 1: Kavramlar ve Genel illkeler", "Bölüm 2: Finansal Tabloların Sunumu", "Bölüm 3: Finansal Durum Tablosu", "Bölüm 4: Kâr veya Zarar Tablosu" olmak üzere 4 farklı bölüm içinde yer almıştır. Ayrıca BOBi FRS'de yer alan "Bölüm 21: İ̧̧ Birleşmeleri", KÜMi FRS'de "Bölüm 19: İ̧̧letme Birleşmeleri" olarak isimlendirilmiştir. Bunun dışında bölüm numaraları eşleşmese de bölüm isimlerinin aynı olduğu görülmektedir.

\subsection{Kavramlar ve Finansal Tablolar İle İlgili Karşılaştırmalar}

Tekdüzen Muhasebe Sistemi'nde bilanço olarak isimlendirilen finansal tablo, TFRS ve BOBi FRS'de olduğu gibi KÜMi FRS'de de finansal durum tablosu olarak isimlendirilmektedir. Tekdüzen Muhasebe Sistemi'ndeki gelir tablosu ise, TFRS'de kar zarar tablosu ve eğer kapsamlı gelir hesaplanmışsa kapsamlı gelir tablosu olarak isimlendirilirken, BOBI FRS ve KÜMi FRS'de kapsamlı gelir hesaplanmadığından tablo, kar veya zarar tablosu olarak isimlendirilmektedir. TFRS ve BOBI FRS' de, finansal durum tablosu ve kar zarar tablosuna ilaveten hazırlanması zorunlu olan nakit akış tablosu ve özkaynak değişim tablosu, KÜMi FRS'de asgari olarak hazırlanması gereken tablolar arasında yer almamaktadır. Bu nedenle KÜMi FRS ekler kapsamında, konsolide finansal tablolar, nakit akış ve özkaynak değişim tablosu formatı bulunmamakta, sadece finansal durum tablosu ve kar zarar tablosu örneği yer almaktadır.

BOBi FRS' de finansal raporlamanın amacı, tam sette olduğu gibi, finansal tablo bilgilerini kullananlara, geleceği tahmin etme ve geçmişi değerlendirme olanağı veren önemli nitelikteki ihtiyaca uygun bilgileri sunmak, tam, tarafsız, hatasız, doğru ve güvenilir bilgileri üreterek gerçeğe uygun sunumu sağlamaktır. Bunun için BOBi FRS'nin ilk bölümünde faydalı finansal bilginin temel özellikleri, ihtiyaca uygunluk ve gerçeğe uygun sunum, destekletici özellikleri ise anlaşılabilirlik, karşılaştırılabilirlik ve zamanında sunum olarak ifade edilmiştir. KÜMi FRS Bölüm 2'de aynı özellikler "Finansal Tablolardaki Bilgilerin Özellikleri" başlığı altında gruplandırma yapılmadan verilmekte ve BOBi FRS ile uyumlu olarak tanımlanmaktadır. Ayrıca yine BOBi FRS ile uyumlu olarak "Genel Finansal Raporlama İlkeleri" başlığı altında "işletmenin sürekliliği, tahakkuk esası, ihtiyatılıık, önemlilik, karşılaştırmalı bilgi, mahsup yasağı, sunumda tutarlılık ve raporlamanın sıklığı" kavramları tanımlanmaktadır.

KÜMi FRS Taslağı Bölüm 1'deki temel ölçüm esasları; maliyet bedeli, gerçeğe uygun değer ve itibari değerdir. KÜMi FRS' de alacak ve borçlar itibari değer ile değerlenmektedir. BOBi FRS'de bir yıldan uzun vadeli alım satımlarda faiz ayrıştırması yapılması gerekiyorken, KÜMi FRS'de varlık alımı ve hasılat kayda alınırken hiçbir zaman faiz ayrıştırması yapılmaz. Dönem içinde faiz ayrıştırması yapılmadığından, dönem sonunda alacak ve borçlar için zorunlu olarak reeskont hesaplanmalıdır. Bu uygulama TFRS ve BOBi FRS uygulamaları ile uyumlu değildir, ancak ülkemizdeki vergi uygulamaları ile uyumludur. 
KÜMi FRS Taslağı Bölüm 3'deki finansal durum tablosu ile ilgili düzenlemelere göre tabloda, küçük ve mikro işletmeler tarafından ihtiyaca göre alt kalemlere yer verilebilir. BOBi FRS ile uyumlu olarak bu bölümde belirtilen özelliklerden herhangi birini taşıyan varlıklar ve yükümlülükler, dönen varlık ve kısa vadeli yükümlülük olarak, bu özellikleri taşımayan kalemler duran varlık ve uzun vadeli yükümlülük olarak sınıflandırıır. Özkaynak sınıfında ödenmiş sermaye, yedekler, geçmiş yıllar kâr/zararı, dönem net kâr/zararı gibi kalemler sunulur. BOBi FRS'de finansal durum tablosunun pasifinde ve özkaynak değişim tablosunda raporlanan "Yeniden Değerleme Yedeği", "Yabancı Para Çevrim Farkları" ve "Korunma Yedeği” gibi özkaynak kalemlerine karşılık, KÜMi FRS finansal durum tablosunda özkaynaklar içinde, "Yeniden Değerleme Değer Artışları" ve "Yabancı Para Çevrim Farkları" hesabı yer almaktadır. KÜMi FRS'de türev ürünler ve korunma muhasebesi yer almamakta ancak BOBi FRS ile uyumlu olarak KÜMi FRS' de de maddi duran varlıkların sonraki ölçümlerinde yeniden değerleme yöntemi kullanılabilmektedir.

BOBI FRS'ye göre sadece büyük işletmeler ertelenmiş vergileri hesaplar ve raporlar ancak, Tekdüzen Muhasebe Sisteminde yer almayan ertelenmiş vergilerin kaydı ve raporlaması KÜMi FRS'de de bulunmamaktadır. KÜMi FRS finansal durum tablosu, Tekdüzen Muhasebe Sistemi'ndeki bilanço formatına yakın olmakla birlikte, Tekdüzen Muhasebe Sistemi'ndeki bilançoda yer almayan canlı varlıklar kalemi, TFRS ve BOBi FRS ile uyumlu olarak KÜMi FRS finansal durum tablosunda dönen ve duran varlıklar grubu içinde yer almakta, ayrıca yatırım amaçlı gayrimenkullerine BOBi FRS hükümlerini uygulamak isteyenler tabloda "yatırım amaçlı gayrimenkuller" kalemine yer vermektedir.

KÜMi FRS'de kar-zarar tablosu, Tekdüzen Muhasebe Sistemi'ndeki gelir tablosundan ve TFRS'lerdeki kar zarar tablosu ve kapsamlı gelir tablosu formatından farklıdır, ancak BOBi FRS ile uyumludur. KÜMi FRS'de kar-zarar tablosunda, esas faaliyet kar-zararını takiben raporlanan dönem gelir-giderleri, diğer faaliyetlerden gelirler/ giderler ve finansal gelirler/giderler olarak gruplandırılmıştır. Ancak KÜMi FRS'de özkaynak yöntemi yer almadığından "Bağlı Ortaklıkların, İştiraklerin ve Müşterek Girişimlerin Kârlarından Paylar" kalemi bulunmamakta, ancak satış hasılatı hesaplanırken BOBi FRS'de olduğu gibi "Tarımsal Faaliyetlerde Gerçeğe Uygun Değer Farkları" da dikkate alınmaktadır.

Konsolide finansal tabloların yer almadığı KÜMi FRS'de, tüm standartlarda olduğu gibi, bir gelir veya gider kalemi kar veya zarar tablosunda ya da dipnotlarda Tekdüzen Muhasebe Sistemi'nde kullanılan "olağandışı kalem" olarak sunulmaz. Ayrıca TFRS ve BOBi FRS ile uyumlu olarak, düzeltilen geçmiş dönem hatalarının ve muhasebe politikalarındaki değişikliklerin etkileri, ortaya çıktıkları dönemin kâr veya zararının bir unsuru olarak değil, geçmiş dönemler için yapılan geriye dönük düzeltmeler olarak raporlanır. Oysa bu hususlara ilişkin Tekdüzen Muhasebe Sistemi'nde bir düzenleme bulunmamaktadır. KÜMi FRS 5. bölümde yer alan "Muhasebe Politikaları, Tahminler ve Hatalar" ile 6. bölümdeki "Raporlama Döneminden Sonraki Olaylar" ile ilgili düzenlemeler BOBi FRS ile uyumludur. Buna göre geriye dönük düzeltme yapıldığında, karşılaştırmalı olarak sunulan en erken dönemin başlangıcına ait ilave bir finansal durum tablosu sunulur. Ancak geriye dönük uygulamanın veya geriye dönük düzeltmenin karşılaştırmalı olarak sunulan en erken dönemin başındaki finansal durum tablosunda yer alan kalemler üzerindeki etkisi önemsizse ilave finansal durum tablosu sunulması gerekmez.

\subsection{Hasılatın Raporlanması}

KÜMi FRS Taslağı 7. bölümde ele alınan hasılat, BOBi FRS'de olduğu gibi mal satışı (satış amacıyla işletme tarafından üretilen ya da yeniden satılmak üzere satın alınan malların satışı), hizmet sunumu, işletmenin yüklenici olduğu inşa sözleşmeleri ve işletme varlıklarının başkaları tarafından kullanılmasından sağlanan faiz, isim hakkı ve kâr payını kapsamaktadır. Bu bölümde yer alan finansal tablolara alma ölçütleri genellikle BOBI FRS ile uyumlu olmakla birlikte, hasılatın ölçümü hususunda farklılık bulunmaktadır. BOBi FRS'de "Hasılat bedelinin, bir yıl veya daha kısa sürede tahsil edilmesinin öngörülmesi durumunda hasılat, vade farkı ayrıştırması yapılmaksızın doğrudan tahsil edilen veya edilmesi beklenen bedel üzerinden ölçülür. Bu bedelin, bir yıldan daha uzun bir vadede tahsil edilmesinin öngörülmesi durumunda ise hasılat, işlemdeki vade farkı ayrıştırılarak ilgili mal veya hizmetin peşin bedeli üzerinden ölçülür ve etkin faiz yöntemine göre hesaplanan vade farkı tutarı faiz geliri olarak muhasebeleştirilir"(BOBi FRS Bölüm 5, madde 9). KÜMi FRS'de ise, ülkemizdeki vergi uygulamalarında olduğu gibi, hasılat, taraflar arasında yapılan anlaşma kapsamında, 
satış iskontoları (kasa ve miktar iskontoları) düşüldükten sonra, vade farkı ayrıştırılmaksızın doğrudan tahsil edilen veya edilmesi beklenen bedel üzerinden ölçülür. KÜMi FRS'de mal satışına ilişkin hasılatın, finansal tablolara alınma ölçütleri ВOBi FRS ile örtüşsmektedir.

BOBi FRS'ye göre, hizmet sunumu ve inşa sözleşmelerinin muhasebeleştirilmesi benzerlik ihtiva etmektedir. Hizmet sunumunun ve inşa sözleşmesinin sonucu güvenilir olarak tahmin edilemiyorsa geri kazanılması beklenen gider tutarı kadar hasılat muhasebeleştirilmekte ve ilgili hizmet sunumu ve inşa sözleşmesine ilişkin herhangi bir kâr ortaya çıkmamaktadır(Sabuncu, 2018: 241). Hizmet sunumuna ilişkin hasılatın kaydı ve raporlamasında, BOBi FRS ile uyumlu düzenlemelerin bulunduğu KÜMi FRS'de, bir işlemin sonucunun güvenilir bir şekilde tahmin edilebildiği durumlarda, ilgili hasılat tutarı, raporlama dönemi sonu itibarıyla işlemin tamamlanma düzeyi dikkate alınarak (tamamlanma yüzdesi yöntemi" kullanılarak) finansal tablolara alınır. Bu yönteme göre hasılat, hizmetin sunulduğu dönemlerde finansal tablolara yansıtılır. Oysa vergi uygulamalarımızda ve Tekdüzen Muhasebe Sistemi'nde bir dönemden uzun süren hizmet işlemlerinde, hasılatın sunumu ve kar zararın hesaplanması, işin tamamlandığı dönem sonu itibariyle gerçekleştirilir, hizmetin sunulduğu önceki raporlama dönemlerinde hasılat ve kar zarar raporlanmaz.

Mal ve hizmetlerin takası durumunda hasılatın ortaya çıkması ile ilgili olarak KÜMi FRS bölüm 7 madde 10'daki düzenlemeler BOBi FRS ile uyumludur. Buna göre, "mal veya hizmetlerin, benzer özelliklere ve değere sahip olmayan mal ya da hizmetlerle ticari bir özü bulunan bir işlem çerçevesinde takası durumunda, hasılat finansal tablolara alınır. Bu durumda söz konusu işlem:

- Alınan mal ya da hizmetin gerçeğe uygun değeri esas alınarak ölçülür. Alınan mal veya hizmetin gerçeğe uygun değerine, varsa, ilgili işlemde alınan (veya ödenen) tutarlar eklenir (veya çıkartılır).

- Alınan mal ya da hizmetin gerçeğe uygun değerinin güvenilir bir şekilde ölçülememesi durumunda elden çıkarılan mal veya hizmetin gerçeğe uygun değeri esas alınır.

- Elden çıkarılan mal veya hizmetin gerçeğe uygun değerinin de güvenilir bir şekilde ölçülememesi durumunda elden çıkarılan mal veya hizmetin defter değeri esas alını."

\subsection{Stoklar ve Satışların Maliyetinin Raporlanması}

KÜMi FRS Taslağı 8. bölümde ele alınan stoklar ile ilgili düzenlemeler de genel olarak BOBi FRS ile uyumludur. Ancak BOBi FRS' de bir yıldan uzun vadeli stok alımlarında, vade ayrıştırması yapıldığı halde KÜMi FRS' de vade ayrıştırması yapılmaz. Ayrıca BOBI FRS' de stoklar, "maliyet bedeli ile net gerçekleşebilir değerden düşük olanı üzerinden ölçülür, değer azalışı değer düşüklüğü zararını oluşturur ve Kâr veya Zarar Tablosunda "Satışların Maliyeti" kalemine yansıtılır"(BOBi FRS Bölüm 6 madde 22). Buna karşılık net gerçekleşebilir değer tanımına yer vermeyen KÜMi FRS'de stoklar, maliyet değeri ile ölçülür ve 19. maddeye göre "Raporlama dönemi sonunda stokların tahmini satış fiyatının maliyet bedelinden \%10 veya daha fazla düşük olması durumunda söz konusu değer düşüklüğü tutarı finansal tablolara yansıtılır. Bu tutar, değer düşüklüğü zararını oluşturur ve Kâr veya Zarar Tablosunda Satışların Maliyeti kaleminde gösterilir". KÜMi'deki değer düşüklüğü vergi uygulamalarımıza uygun şekilde tespit edilmekte, ancak değer azalışı BOBi FRS'de olduğu gibi satış maliyetini artıı bir şekilde kar zarar tablosunda raporlanmaktadır.

Stoklarda değer düşüklüğünün iptali ile ilgili KÜMi FRS'deki düzenlemeler, BOBi FRS ile aynıdır. Buna göre, değer düşüklüğü iptal edildiğinde, ilgili stokun maliyet bedeli esas alınır ve stokun değer düşüklüğünden sonra belirlenen değeri, stokun maliyet bedelini aşamaz. Değer düşüklüğünün iptali ile ilgili kayda alınan gelir, satışların maliyeti ile ilişkilendirilmez. Tekdüzen muhasebe Sisteminde ise, stoklar ile ilgili hem değer düşüklüğü zararı, hem de değer düşüklüğünün iptalindeki gelir, satışların maliyeti ile ilişkilendirilmez, olağan faaliyet gideri/geliri olarak raporlanır.

KÜMi FRS'de stoklara ilişkin borçlanma maliyetleri (stok alımı için için kullanılan krediler nedeniyle katlanılan kur farkları dâhil finansman giderleri) oluştukları dönemde kâr veya zarara yansıtııırken, BOBi FRS'de, üretilmesi normal şartlar altında bir yıldan daha uzun süren stoklar için katlanılan borçlanma maliyetleri satışa hazır hale geldiği tarihe kadar stokların maliyetine dâhil edilir. 
BOBI FRS ve vergi uygulamalarımız ile uyumlu olarak KÜMi FRS'de mamul maliyetleri, tam maliyet yöntemine göre ve üretim giderlerinin gerçekleşmiş tutarları esas alınarak fiili maliyet yöntemine göre belirlenir. Ancak sonuçlar fiili maliyete yakınsa, standart maliyet yöntemi veya perakende yöntemi gibi stok maliyeti ölçüm teknikleri kullanılabilir.

BOBI FRS'de olduğu gibi KÜMi FRS'de de "Tarımsal Faaliyetler" uyarınca canlı varlıkların hasadından elde edilen tarımsal ürünlerden oluşan stoklar, finansal tablolara ilk kez alınırken hasat anındaki satış maliyetleri düşülmüş gerçeğe uygun değeri üzerinden ölçülür ve bu değer, stokun hasat anındaki maliyetidir. VUK 277. maddesine göre ise, canlı varlıklar maliyet bedeli ile ölçülmekte, zirai işletmelere dâhil olan hayvanların maliyet bedelinin tespiti mümkün olmayan hallerde emsal bedeli kullanılmaktadır

Stokların takas yoluyla edinimi ile ortak ürün ve yan ürün ile ilgili BOBI FRS' de yer alan düzenlemelere, KÜMi FRS'de yer verilmemiştir.

\subsection{Finansal Varlık ve Yükümlülüklerin Raporlanması}

KÜMi FRS Taslağı bölüm 10 kapsamında finansal varlık ve finansal yükümlülüklere ve işletmenin ihraç ettiği özkaynak araçlarına ilişkin muhasebe ilkeleri düzenlenmiştir. Bu bölümde BOBi FRS 9,10, ve 11 . bölümlerinde yer alan düzenlemeler sadeleştirilerek ele alınmış, BOBi FRS'de ayrı bölümlerde yer alan bağı ortaklıklar, iştirakler ve müştereken kontol edilen işletmelerin ölçümüne ilişkin hükümler de, bu bölüm kapsamına alınmıştır.

KÜMi FRS'de finansal araç, finansal varlık ve finansal yükümlülük tanımları BOBi FRS ile uyumludur. Ancak BOBI FRS'de bir yıldan uzun vadeli alacak ve borçlar itfa edilmiş değeri ile ölçülerek, etkin faiz yöntemine göre hesaplanan faiz kar zararda raporlanırken, KÜMi FRS'de tüm alacak ve borçlar, vergi mevzuatımızda olduğu gibi itibari değeri ile ölçülür ve hesap dönemi sonlarında reeskont işlemine tabi tutulur. MSUGT'a göre sadece senede bağlanmış alacak ve borçlar için yapılabilen ve ihtiyari olan reeskont uygulaması, KÜMi FRS'de tüm alacak ve borçlar için zorunludur. İşletme dönem sonlarında makul bir gerekçeye dayanarak tahsili şüpheli hale gelen ticari ve diğer alacaklarını tahmin eder ve bu alacaklar için 10.21-10.27 paragrafları uyarınca değer düşüklüğü karşılığı hesaplar. Gerçeğe uygun değeri üzerinden ölçülen finansal varlıklar dışında kalan tüm finansal varlıklara ilişkin değer düşüklüğü hesaplanırken, değer düşüklüğüne dair KÜMi FRS bölüm 10, 23 ve 24. maddelerinde sayılanlar gibi gözlemlenebilir bir kanıt varsa, değer düşüklüğü zararı kâr veya zarara yansıtılır.

KÜMi FRS'de ticari ve diğer alacak ve borçlar dışındaki, borçlanma araçlarının ilk ölçümü gerçeğe uygun değeri (işlem fiyatı) üzerinden gerçekleştirilir, bunların edinimiyle veya ihracıyla doğrudan ilişkilendirilebilen işlem maliyetleri gider olarak kâr veya zarara yansıtılır. Borçlanma araçlarının sonraki dönemlerdeki ölçümünde, işlem fiyatına, raporlama dönemi sonuna tahakkuk eden faiz gelir veya giderleri eklenir, dönem sonuna kadar gerçekleşmiş tüm ana para geri ödemeleri ve tüm faiz ödeme veya tahsilatları çıkartılır ve eğer varsa değer düşüklüğü zararları da düşüldükten sonraki değeri ile raporlanır.

MSUGT'da, KÜMi FRS'de olduğu gibi, borçlanma aracı niteliğindeki menkul kıymet yatırımları ilk edinimde işlem fiyatı ile kayda alınır ve işlem maliyetleri kar zarara yansıtılır. Vergi uygulamalarımızda sonraki dönemlerdeki değerlemede ise, varsa borsa rayici, yoksa alış bedeline, vade sonuna kadar işleyen faizin eklenmesiyle bulunan tutar, işletmenin ihraç ettiği tahviller için itibari değeri, banka kredileri işlemiş faiziyle birlikte mukayyet değeri kullanılmaktadır. BOBi FRS'de ise borçlanma araçları, ilk muhasebeleştirmede, işlem maliyetleri de dahil edilmiş işlem fiyatı üzerinden, sonraki dönemlerde itfa edilmiş maliyet ile değerlenir, ortaya çıkan fark ve varsa değer düşüklüğü zararı, kar zarara aktarılır.

KÜMi FRS'de, "bağlı ortaklık, müştereken kontrol edilen işletme veya iştirak yatırımlarındaki paylar dâhil, borsada ve/veya teşkilatlanmış diğer piyasalarda işlem gören özkaynak araçları, ilk defa finansal tablolara alınırken gerçeğe uygun değeri (işlem fiyatı) üzerinden ölçülür ve işlem maliyetlerinin tamamı doğrudan kâr veya zarara yansıtılır. Bu özkaynak araçlarının sonraki ölçümü de gerçeğe uygun değeri (piyasa değeri) üzerinden gerçekleştirilir ve ortaya çıkan değer farkları kâr veya zarara yansıtılır." BOBi FRS'de ise, 
bağlı ortaklık, müştereken kontrol edilen işletme veya iştirak yatırımlarındaki paylar için özkaynak yöntemi kullanılır, bunlar dışındaki hisse senedi yatırımları için KÜMi FRS ile aynı esaslar geçerlidir.

KÜMi FRS'ye göre, BOBi FRS ile uyumlu olarak, borsada ve/veya teşkilatlanmış diğer piyasalarda işlem görmeyen özkaynak araçlarının ilk ölçümü, işlem fiyatları ve işlem maliyetlerinin toplamından oluşan maliyet bedeli üzerinden gerçekleştirilir. Bu özkaynak araçlarının sonraki ölçümü ise, maliyet bedelinden varsa değer düşüklüğü zararları düşülerek gerçekleştirilir ve değer azalışları gider olarak kar zarara yollanır. BOBi FRS'de işletme, korunma aracı ile korunan kalem arasında korunma ilişkisi tanımlayarak korunma muhasebesini intiyari olarak uygulayabilir, ancak KÜMI FRS ve MSUGT kapsamında korunma muhasebesi gibi konsolide finansal tablolar da yer almamaktadır. MSUGT'da hisse senetlerinin ilk kaydı, işlem maliyetleri hariç işlem fiyatı (alış bedeli) ile yapılmakta ve sonraki dönemlerde maliyet yöntemi kullanılmaktadır. Ancak vergi uygulamalarımız hisse senetlerinin sonraki dönemlerdeki değerlemesinde alış bedeli ile değerlemeyi esas aldığından değer azalış zararı, kanunen kabul edilmeyen gider niteliğini taşımaktadır.

\subsection{Maddi - Maddi Olmayan Duran Varlıkların Raporlanması}

KÜMi FRS Taslağı bölüm 11'e göre “Maddi duran varlıklar, mal veya hizmet üretiminde veya arzında kullanılmak, başkalarına kiraya verilmek veya idari amaçlar çerçevesinde kullanılmak üzere elde tutulan ve birden fazla dönemde kullanımı öngörülen fiziki kalemlerdir (madde 3). Kira geliri veya değer artış kazancı ya da her ikisini birden elde etmek üzere elde tutulan gayrimenkuller bu bölüm hükümleri uyarınca maddi duran varlık olarak değerlendirilir. Ancak, isteğe bağlı olarak, işletmeler söz konusu gayrimenkullere BOBi FRS Bölüm 13 Yatırım Amaçlı Gayrimenkuller hükümlerini uygulamayı seçebilir (madde 4). Buna göre, KÜMi FRS'de yatırım amaçlı gayrimenkuller ayrı bir bölümde ele alınmamış ancak BOBi FRS gereklerinin uygulanarak yatırım amaçlı gayrimenkullerin finansal durum tablosunda ayrı raporlanması isteğe bırakılmıştır.

KÜMi FRS'ye göre, maddi ve maddi olmayan duran varlıklar, ilk kayda almada maliyet bedeliyle ölçülür ve maliyet bedelinin tespiti BOBI FRS ile uyumlu olmakla birlikte, vadeli alımlarda maliyetin tespitinde bazı farklııklar bulunmaktadır. BOBi FRS'de bir yıldan uzun vadeli bir ödeme karşılığında satın alınan maddi ve maddi olmayan duran varlıklar, vade farkı ayrıştırılarak peşin fiyat üzerinden ölçüldüğü halde, KÜMi FRS'de faiz ayrıştırması bulunmamakta, vergi uygulamalarımızda olduğu gibi maliyet değerinin içinde vade farkı da yer almaktadır.

BOBi FRS'ye göre, inşası normal şartlar altında bir yıldan daha uzun süren maddi duran varlıklar için kullanılan kredilerin borçlanma maliyetleri kullanıma hazır hale geldiği tarihe kadar maddi duran varlığın maliyetine eklenir. Vergi uygulamalarımıza göre kredi faizi ile döviz kredisine ilişkin kur farkları, varlığın iktisap edildiği dönem sonuna kadar maliyete eklenir, bu dönemden sonra ise maliyete eklenebilir ya da gider olarak kaydedilebilir (Doğan, 2018: 123). Kredi faizlerine ilişkin olarak yayımlanan 163 Sıra No.lu VUK Genel Tebliğinde "Yatırımların finansmanında kullanılan kredilerle ilgili kur farkı ve faizlerden kuruluş dönemine ait olanların sabit kıymetle birlikte amortisman yoluyla itfa edilmek üzere yatırım maliyetine eklenmesi gerekmekte; işletme dönemine ait olanların ise, ilgili bulundukları yıllarda doğrudan gider yazılması ya da maliyete intikal ettirilmek suretiyle amortismana tabi tutulması," açıklamalarına yer verilmiştir. Vadeli alımlarda satıcı tarafından faturaya yansıtılan vade farkları da finansman gideri niteliğinde olduğundan aynı esaslara göre değerlendirilmektedir (Bağırgan, 2019: 6). KÜMi FRS'de maddi ve maddi olmayan duran varlıklara ilişkin borçlanma maliyetleri oluştukları dönemde kâr veya zarara yansıtılır.

Vergi uygulamalarımızdan farklı ancak BOBi FRS ile uyumlu olarak, KÜMi FRS'de arazi ve binalar, birbirinden ayrılabilir varlıklardır ve söz konusu varlıklar birlikte edinilmiş olsalar bile ayrı olarak finansal tablolara alınırlar. Öte yandan ВOBi FRS ve vergi uygulamalarımızda olduğu gibi, KÜMi FRS'de varlığın ekonomik ömrünü uzatarak veya kapasitesini genişleterek kendisinden gelecekte elde edilecek faydayı artıran harcamalar varlığın defter değerine dâhil edilir.

Vergi uygulamalarımızda maddi ve maddi olmayan duran varlıklar maliyet değeri ile değerlenmektedir. KÜMi FRS'de ise, BOBi FRS ile uyumlu olarak, maddi olmayan duran varlıklar için sadece maliyet yöntemi uygulanabiliyor iken maddi duran varlıklar için maliyet ya da yeniden değerleme yönteminin kullanılabileceği belirtilmektedir. Maliyet yöntemi uygulandığında, her raporlama dönemi sonunda maddi ve 
maddi olmayan duran varlık kalemlerinde değer düşüklüğü olup olmadığının tespiti yapılarak, varsa değer düşüklüğü zararının finansal durum tablosunun aktifinde eksi olarak ve kar zarar tablosunda da gider olarak raporlanır. Vergi uygulamalarımızda ve Tekdüzen Muhasebe Sisteminde ise maddi ve maddi olmayan duran varlıklar için dönem sonunda sadece amortisman hesaplanır ve kayıtlanır, değer düşüklüğünün hesaplanıp raporlanması mümkün değildir.

KÜMi FRS Taslağı'na göre, maddi duran varlıklar için edinimden sonraki ölçümlerde yeniden değerleme yöntemi kullanılabilir ve bu durumda, "yeniden değerlenmiş tutar, yeniden değerlemenin yapıldığı tarihteki gerçeğe uygun değerdir. Bu tarihten sonra varlığın yeniden değerlenmiş tutarı; varlığın yeniden değerlendiği tarihteki gerçeğe uygun değerinden, yeniden değerlemenin yapıldığı tarihten sonraki birikmiş amortisman tutarı ve birikmiş değer düşüklüğü zararı indirilerek hesaplanır. Yeniden değerleme, ilgili varlığın defter değerinin raporlama dönemi sonundaki gerçeğe uygun değerinden önemli ölçüde farklı olmamasını sağlayacak şekilde düzenli aralıklarla yapılır"(KÜMi FRS 11/17). Gerçeğe uygun değerin tespitinde, BOBi FRS Bölüm 9 Finansal Araçlar ve Özkaynaklar'da yer alan düzenlemelerin uygulanacağı ifade edilmektedir.

KÜMi FRS Taslağı'nda yeniden değerleme yönteminin uygulanması, tam set standartlar ile uyumlu olarak ВОВі FRS düzenlemeleri paralelindedir. Buna göre, "Değer artışları finansal durum tablosunda özkaynaklarda "Yeniden Değerleme Değer Artışları" kaleminde raporlanır. Eğer aynı varlı̆ı̆ daha önce gider kaydedilen değer azalışı varsa, önce bunun iptali için gelir kaydı yapılır. Değer azalışı olduğunda, varsa önce aynı varlık için özkaynaklardaki "Yeniden Değerleme Değer Artışları" kaleminde yer alan tutardan indirilir, kalan tutar gider kaydedilir. Bir maddi duran varlık finansal tablo dışı bırakıldığında, bu varlığa ilişkin olarak "Yeniden Değerleme Değer Artışları" kaleminde yer alan birikmiş tutar "Geçmiş Yıllar Kârları/Zararları" kalemine aktarılır"(KÜMi FRS 11/20-21).

Vergi uygulamalarımızda ihtiyari olan amortisman, BOBi FRS ve KÜMi FRS'de zorunludur. Maddi ve maddi olmayan duran varlıklar kullanıma hazır olduğunda amortisman ayrılmaya başlanır ve her zaman kıst amortisman uygulanır. Oysa vergi uygulamalarımızda kıst amortisman sadece binek otomobilleri için uygulanmaktadır.

Vergi uygulamalarımızda kalıntı değer dikkate alınmaz ancak standart uygulamalarında amortismana tâbi tutar, maddi duran varlı̆ı̆ maliyet bedelinden kalıntı değerin indirilmesi suretiyle belirlenir. Eğer kalıntı değer, önemsiz ise, amortismana tâbi tutarın belirlenmesinde dikkate alınmaz.

Vergi uygulamalarımızda varlıkların faydalı ömürleri Maliye Bakanlığı tarafından belirlendiği halde, tüm standartlara göre faydalı ömür, işletme tarafından gerçekçi tahminlere dayanılarak belirlenir. KÜMi FRS'ye göre, BOBi FRS ile uyumlu olarak, maddi olmayan duran varlıklarda faydalı ömrü belirsiz olanlar 5-10 yıl arasında itfa edilir.

Vergi uygulamalarımızda amortisman yöntemleri sınırlandırılmış olmasına karşııık, standartlarda amortisman uygulaması için çeşitli yöntemler kullanılabilir. Varlığın kullanım şekli değiştiğinde, beklenmeyen ölçüde aşınma veya yıpranma meydana geldiğinde, teknolojik gelişmeler olduğunda, piyasa fiyatlarında değişiklikler meydana geldiğinde veya benzeri durumlarda varlığın kalıntı değeri veya faydalı ömrü işletme tarafından değiştirilebilir.

KÜMi FRS Taslağı'na göre, işletmede oluşturulan şerefiye ile maddi olmayan unsurlar için katlanılan harcamalar, varlık olarak finansal tablolara alınan başka bir varlığın maliyetinin bir parçası olmadığı sürece maddi olmayan duran varlık olarak aktifleştirilmez. Bu kapsamda araştırma ve geliştirme giderleri ile kuruluş ve örgütlenme giderlerinin aktifte raporlanmayarak gider kaydedilmesi gerekmektedir. BOBi FRS'de ise araştırma ve geliştirme giderleri ayrıştııılmıştır, araştırma giderlerinin kar zarara yansıtılması, nitelikleri tanımlanmış olan geliştirme giderlerinin ise aktifte raporlanabileceğine ilişkin düzenlemeler bulunmaktadır. Tekdüzen Muhasebe Sisteminde, araştırma ve geliştirme giderleri ile kuruluş ve örgütlenme giderlerinin aktifleştirilmesi ya da gider olarak kaydedilmesi mümkündür.

Maddi ve maddi olmayan varlıklardaki değer azalışları, vergi uygulamalarımızda ve Tekdüzen Muhasebe sisteminde yer almamakta, ancak KÜMi FRS bölüm 16 “Varlıklarda Değer Düşüklüğü” hükümlerine göre hesaplanmaktadır. Bu bölüm BOBi FRS ile uyumlu düzenlemeler içermekle birlikte, BOBi FRS'deki 
şerefiye ve nakit yaratan birim ile ilgili düzenlemeler KÜMi FRS'de yer almamış, geri kazanılabilir değer kavramı içinde kullanım değeri kavramına yer verilmemiştir. KÜMi FRS'ye göre “Her raporlama dönemi sonunda, her bir varlığın değer düşüklüğüne uğradığına ilişkin bir göstergenin mevcut olup olmadığı değerlendirilir. Bu tür bir göstergenin mevcut olması durumunda, ilgili varlığın defter değeri ile satış maliyetleri düşülmüş gerçeğe uygun değeri karşılaştırılır"( KÜMi FRS Bölüm 16 madde 3). BOBi FRS'den farklı olarak "Varlığın satış maliyetleri düşülmüş gerçeğe uygun değerinin, defter değerinden \%10 veya daha fazla düşük olması durumunda varlıklara ilişkin değer düşüklüğü zararları kâr veya zarara yansıtılır. Ancak yeniden değerlenmiş tutarı üzerinden ölçülen maddi duran varlıklara ilişkin değer düşüklüğü zararları "Bölüm 11 Maddi Duran Varlıklar" uyarınca yeniden değerleme değer azalışı olarak dikkate alını" (KÜMi FRS Bölüm 16 madde 8) düzenlemesi bulunmaktadır. "Kâr veya zarara yansıtılan değer düşüklüğü zararları Kâr veya Zarar Tablosunda varlığın kullanıldığı işletme fonksiyonuna ilişkin giderlerin yansıtıldığı kalemde gösterilir. Örneğin, pazarlama bölümüyle ilgili olarak kullanılan varlığa ilişkin değer düşüklüğü zararı "Pazarlama Giderleri" kaleminde, üretim bölümüyle ilgili kullanılan varlıklara ilişkin değer düşüklüğü zararı ise "Satışların Maliyeti" kaleminde gösterilir" (KÜMi FRS Bölüm 16 madde 9).

MSUGT'da maddi olmayan duran varlıklar içinde raporlanan şerefiye, BOBi FRS'de olduğu gibi "iş̧letme Birleşmeleri" ile ilgili 19. bölümde ele alınmıştır. Buna göre, "İşletme birleşmesi, bir işletmenin başka bir işletmeyi veya iş tanımını karşılayan bir unsuru (örneğin, işletmenin bağımsız bir faaliyet kolu) tamamen devralması (edinmesi) veya işletmelerin yeni bir işletme içinde bir araya gelmeleriyle gerçekleşir. İşletme birleşmesi, çeşitli şekillerde gerçekleşebilir. Örneğin; bir işletme birleşmesi, edinen işletmenin edinilen işletmenin net varlıklarını satın alması veya edinilen işletmenin özkaynak paylarını edinmesi, iki ayrı işletmenin yeni kurulan bir işletme çatısı altında birleşmesi ya da edinilen tarafın tasfiye edilerek edinen işletme tarafından devralınması şeklinde gerçekleşebilir" (KÜMi FRS Bölüm 19 madde 2-3). İşletme birleşmelerinin finansal tablolara alınmasında BOBi FRS hükümlerinin uygulanacağı belirtilmektedir. Buna göre, edinen işletme birleşme tarihinde iş birleşmesinde ortaya çıkan şerefiyeyi varlık olarak kayda alır.

Şerefiye tutarı; birleşme tarihinde, iş birleşmesinin maliyetinin, edinilen tarafın bu bölüme göre kayda alınan ve ölçülen net varlıklarındaki edinen işletmenin payını aşan kısmıdır. BOBi FRS ile uyumlu olarak, KÜMi FRS' de de şerefiye amortismana tabi tutulur.

Şerefiye sonraki dönemlerde, ilk kayda alındığı tutardan birikmiş itfa payları düşülerek ölçülür. Şerefiyenin faydalı ömrünün güvenilir bir şekilde tahmin edilemediği durumlarda şerefiye 10 yılda itfa edilir. Şerefiye değer düşüklüğü testine tâbi tutulmaz (Gücenme Gençoğlu, 2017: 9)

KÜMi FRS Taslağı Bölüm 13 kapsamındaki kiralamalar ile ilgili düzenlemeler genel olarak BOBi FRS ile ve Vergi Usul Kanunu'nda finansal kiralama ile ilgili düzenlemeler ile uyumludur. Ancak BOBi FRS'de yer alan, bir varlığın satışını ve aynı varlığın geri kiralanmasını ifade eden satış ve geri kiralama işlemleri KÜMi FRS'de ve vergi düzenlemelerimizde yer almamaktadır.

\subsection{Devlet Teşvikleri}

KÜMi FRS Bölüm 15 kapsamındaki Devlet Teşvikleri ile ilgili düzenlemeler genel olarak BOBi FRS ile uyumludur. Ancak BOBi FRS'de bölüm 16 madde 5 kapsamındaki "Devlet tarafından sağlanan ve önceden belirlenen şartlar karşılandığında devletin feragat ettiği krediler devlet teşviki olarak dikkate alınır. Ayrıca piyasa faiz oranından düşük bir faiz oranıyla devletten alınan bir krediden sağlanan fayda da devlet teşviki olarak kabul edilir" düzenlemesi KÜMi FRS'de yer almamıştır. Ayrıca BOBi FRS bölüm 16 madde 9'da yer alan "Piyasa faiz oranından düşük bir faiz oranıyla devletten alınan krediler, bu kredi için devlete yapılacak geri ödemelerin benzer bir kredi için uygulanan piyasa faiz oranıyla iskonto edilmesiyle hesaplanan bugünkü değeri üzerinden ölçülerek Finansal Durum Tablosunda "Diğer Finansal Yükümlülükler" kalemi içinde gösterilir. Devletten alınan kredi tutarı ile Finansal Durum Tablosuna yansıtılan finansal yükümlülük arasındaki fark bu bölüm uyarınca devlet teşviki olarak muhasebeleştirilir" düzenlemesi de KÜMi FRS'de yer almamıştır. BOBi FRS ile uyumlu olan diğer düzenlemelere göre KÜMi FRS'de; teşvik, alınan ya da alınacak olan varlığın gerçeğe uygun değeri üzerinden ölçülür. Devlet teşvikleri aşağıdaki şekilde finansal tablolara alınır: 
- İşletmenin gelecekte herhangi bir performans şartını yerine getirmesini gerektirmeyen ya da performans şartını önceden yerine getirdiği teşvikler, alındıkları anda kâr veya zarara yansıtıır.

- İşletmenin gelecekte belirli performans şartlarını yerine getirmesini gerektiren teşvikler, performans şartları karşılandığı anda kâr veya zarara yansıtııır. Bu teşvikler alındıkları andan kâr veya zarara yansıtılıncaya ya da performans şartları karşılanamadığı için iade edilene kadar Finansal Durum Tablosunda "Ertelenmiş (Gelecek Aylara Ait) Gelirler ve Gider Tahakkukları" kalemi içerisinde gösterilir (KÜMi FRS Bölüm 15 madde 6-7).

Vergi uygulamalarımız açısından 176 sıra nolu VUK Genel Tebliğinde, teşvik belgeli yatırımlar dolayısıyla alınan destekleme primlerinin hasılat olarak da yazılabileceği ya da sabit yatırımların maliyet bedellerinden de düşülebileceği belirtilmiştir.

\subsection{Karşılıklar, Şarta Bağıı Yükümlülükler ve Şarta Bağlı Varlıklar}

KÜMi FRS Taslağı bölüm 17'de ele alınan “Karşılıklar, Şarta Bağı Yükümlülükler ve Şarta Bağıı Varlıklar" ile ilgili düzenlemeler genel olarak BOBi FRS ile uyumlu olmakla birlikte, BOBi FRS bölüm 19 madde 13'e göre karşılık tutarı "yükümlülüğün yerine getirilmesi için yapılması beklenen harcama tutarı ile ya da paranın zaman değerinin etkisinin önemli olduğu durumlarda, yükümlülüğün yerine getirilmesi için yapılması beklenen harcamaların bugünkü değeri üzerinden ölçülebilir." KÜMi FRS'de ise raporlanacak olan karşılık tutarının bugünkü değeri hesaplanmaz, 19. bölümdeki madde 9'a göre, "Karşılık, raporlama dönemi sonu itibarıyla yükümlülüğün yerine getirilmesi için yapılması gereken harcamaya ilişkin en gerçekçi tahmin üzerinden ölçülür." Bunun dışında karşılıkların tanımı, finansal tablolara alınmasına ilişkin koşullar, karşılıkların ölçümünde tahminlerin kullanımı ve karşılıklara ilişkin tazminatlara ilişkin tüm düzenlemeler BOBi FRS' de olduğu gibidir.

"Kıdem tazminatı yükümlülükleri raporlama dönemi sonu itibarıyla tahmin edilir ve bu tahmin nedeniyle cari dönemde ortaya çıkan kıdem tazminatı yükümlülük artışları hesaplanarak gider olarak kâr veya zarara yansıtııır. Kıdem tazminatı yükümlülükleri; iş gücü devir hızı ve önceki yıllara ilişkin kıdem tazminatı gerçekleşmeleri gibi etkenler de dikkate alınarak, çalışanların ilgili döneme ilişkin kıdeme esas ücreti üzerinden hesaplanır" (KÜMi FRS Bölüm 17 madde 16).

Vergi uygulamalarımızda ve Tekdüzen Muhasebe Sisteminde karşılık kavramı hem varlıklardaki değer azalışları hem de şarta bağlı yükümlülükler için kullanıldığı halde, muhasebe standartlarında karşılık, "Gerçekleşme zamanı veya tutarı belli olmayan yükümlülüktür. Karşılık ifadesi, bir yükümlülüğün finansal tablolara alınmasını gerektirmeyen, varlıkların defter değerlerine ilişkin düzeltmeleri (şüpheli alacaklara ve diğer varlıklara ilişkin değer düşüklükleri gibi) kapsamaz" (KÜMi FRS Bölüm 17 madde 4).

KÜMi FRS' de şarta bağlı yükümlülükler ve şarta bağlı varlıklar BOBi FRS'deki gibi tanımlanır ve bunlar finansal durum tablosunda raporlanmaz, eğer işletmeden kaynak çıkışı veya işletmeye kaynak girişi ihtimali çok düşük değilse, dipnotlarda açıklanır.

\subsection{Yabancı Para Çevrim İşlemleri}

BOBi FRS'de yer alan yabancı bağlı ortaklık, müşterek girişim ve iştiraklerin finansal tablolarının konsolidasyonuna ilişkin düzenlemeler, konsolide finansal tabloların hazırlanmadığı KÜMi FRS'de yer almamaktadır. Yabancı para cinsinden işlemlere ilişkin muhasebe ilkeleri BOBi FRS ile uyumlu olarak, KÜMi FRS bölüm 18'de yer almaktadır. Buna göre, "Yabancı para cinsinden işlemler ilk defa finansal tablolara alınırken, yabancı para birimindeki tutar, işlem tarihindeki TCMB tarafından belirlenen döviz alış kuru kullanılarak ağırlıkla kullanılan para birimine çevrilir. Uygulama kolaylığı açısından, işlem tarihindeki kura yakın bir kurun kullanılması mümkündür. Örneğin; haftanın, ayın ya da yılın ortalama kuru, o dönem içinde gerçekleşen yabancı para cinsinden tüm işlemlere uygulanabilir. Ancak, döviz kurunun önemli ölçüde dalgalanması durumunda ortalama kur kullanılamaz "(KÜMi FRS Bölüm 18 madde 7-8). BOBi FRS'de bu çevirinin işlem tarihindeki spot kur kullanılarak yapılması gerektiği belirtilmekte, "spot kur, hemen teslim halindeki geçerli olan döviz kuru" olarak tanımlanmaktadır (BOBi FRS Bölüm 20 madde 8). Tekdüzen 
Muhasebe Sisteminde yabancı para cinsinden işlemler, işlemin gerçekleştiği kur üzerinden ulusal paraya çevrilerek kayıtlanmaktadır.

Sonraki (dönem sonundaki) ölçüm ise varlık veya yükümlülüğün parasal veya parasal olmayan kalem oluşuna göre farklılık göstermektedir (KÜMi FRS Bölüm 18 madde 9-17) "Parasal kalemler, sabit veya belirlenebilir bir tutarda para olarak alınacak veya ödenecek olan varlık ve yükümlülükler ile elde tutulan nakittir. Parasal bir kalemin temel niteliği, sabit ya da belirlenebilir tutarda para biriminin alınması hakkı ya da ödenmesi yükümlülüğüdür." Yabancı para cinsinden parasal kalemler, TCMB tarafından belirlenen dönem sonundaki döviz alış kuru (BOBi FRS'ye göre dönem sonundaki spot kur) kullanılarak ağırlıkla kullanılan para birimine çevrilir. Parasal kalemlerin kur farkı kazanç veya kayıpları oluştukları dönemde kâr veya zarara yansıtılır ve Kâr veya Zarar Tablosunun ilgili kaleminde gösterilir. Örneğin ticari alacak ve borçlara ilişkin kur farkı kazanç veya kayıpları "Esas Faaliyetlerden Diğer Gelirler- Giderler" olarak raporlanırken, banka mevduatlarına veya alınan banka kredilerine ilişkin olarak ortaya çıkan kur farkı kazanç veya kayıpları esas faaliyet dışı gelir- gider olarak raporlanır.

Buna karşııık, stoklar, maddi duran varlıklar, maddi olmayan duran varlıklar, şerefiye gibi "Parasal olmayan bir kalemin temel niteliği, sabit ya da belirlenebilir tutarda para biriminin alınması hakkının (ya da ödenmesi yükümlülüğünün) mevcut olmamasıdır". Parasal olmayan kalemler, maliyet bedelleri üzerinden ölçülüyorsa işlem tarihindeki kurdan; yabancı para cinsinden gerçeğe uygun değerleri üzerinden ölçülüyorsa gerçeğe uygun değerin belirlendiği tarihte TCMB tarafından belirlenen döviz alış kuru üzerinden (BOBi FRS'de gerçeğe uygun değerin belirlendiği tarihteki spot kurdan) ağırlıkla kullanılan para birimine çevrilir.

Bazı parasal olmayan kalemlerin değeri iki veya daha fazla tutarın karşılaştırılması suretiyle belirlenmektedir. Örneğin değer düşüklüğü göstergeleri tespit edilen maddi duran varlıklar satış maliyetleri düşülmüş gerçeğe uygun değeri ile defter değerinin düşük olanı üzerinden gösterilmektedir. Bu tür durumlarda her bir tutar, belirlendiği tarihteki TCMB tarafından belirlenen döviz alış kuru kullanılarak ağırlıkla kullanılan para birimine çevrilir. Örneğin, satış maliyetleri düşülmüş gerçeğe uygun değer, değer düşüklüğü testi açısından dönem sonunda belirleniyorsa çevrim işlemi, dönem sonu kuru kullanılarak yapılır.

"Bazı parasal olmayan kalemlerin değeri iki veya daha fazla tutarın karşılaştırılması suretiyle belirlenmektedir. Örneğin değer düşüklüğü göstergeleri tespit edilen maddi duran varlıklar satış maliyetleri düşülmüş gerçeğe uygun değeri ile defter değerinin düşük olanı üzerinden gösterilmektedir." Bu tür durumlarda her bir tutar, belirlendiği tarihteki TCMB tarafından belirlenen döviz alış kuru (BOBi FRS'de belirlendiği tarihteki kur) kullanılarak ağırlıkla kullanılan para birimine çevrilir. Örneğin, satış maliyetleri düşülmüş gerçeğe uygun değer, değer düşüklüğü testi açısından dönem sonunda belirleniyorsa çevrim işlemi, dönem sonu kuru kullanılarak yapılır.

"Parasal olmayan kalemlere ilişkin ortaya çıkan kur farkı kazanç veya kayıpları, ilgili kaleme ilişkin değer değişimlerinin yansıtıldığı Kâr veya Zarar Tablosu kalemi kullanılarak kâr veya zarara yansıtılır."

İşletmenin finansal tablolarını ağılıkla kullanılan para biriminden farklı bir para biriminden sunması durumunda (örneğin, ağırlıkla kullanılan para birimi Euro olan bir işletmenin TL cinsinden finansal tablolarını sunması) aşağıdaki işlemler uygulanarak çevrim gerçekleştirilir:"

- Cari raporlama dönemine ait finansal durum tablosundaki varlık ve yükümlülükler ve karşılaştırmalı olarak sunulan finansal durum tablosundaki varlık ve yükümlülükler raporlama tarihindeki TCMB tarafından belirlenen döviz alış kuru (BOBi FRS'de raporlama tarihindeki spot kur) üzerinden çevrilir.

- Karşılaştırmalı dönemlere ilişkin bilgiler dâhil, gelir, gider ve özkaynak kalemleri işlem tarihlerindeki döviz alış kurlarından (BOBi FRS'de işlem tarihlerindeki döviz kurlarından) çevrilir. Uygulama kolaylığı açısından, gelir, gider ve özkaynak kalemlerinin çevriminde işlem tarihindeki gerçek kura yaklaşan bir kurun kullanılması mümkündür. Örneğin; dönemin ortalama kuru tüm gelir, gider ve özkaynak kalemlerinin çevriminde kullanılabilir. Ancak, döviz kurunun önemli ölçüde dalgalanması durumunda ortalama kur kullanılamaz. 
- Ortaya çıkan tüm kur farkları ise özkaynaklarda "Yabancı Para Çevrim Farkları" kalemi içerisinde gösterilir.

KÜMi FRS'de "Yüksek Enflasyonlu Ekonomilerde Finansal Raporlama ile ilgili Düzenlemeler" yer almadığı için, BOBi FRS' de bulunan "Ağırlıkla kullanılan para birimi, yüksek enflasyonlu bir ekonominin para birimi olan bir işletmenin, finansal tablolarının çevirisi ile ilgili düzenlemeler KÜMi FRS Bölüm 18 kapsamında yer almamaktadır.

VUK'a göre, yabancı para cinsinden parasal ve parasal olmayan kalemler Maliye Bakanlığı'nca belirlenen kur üzerinden çevrilmektedir VUK madde 280'e göre, "Yabancı paralar borsa rayici ile değerlenir. Borsa rayicinin takarrüründe muvazaa olduğu anlaşılırsa bu rayiç yerine alış bedeli esas alınır. Yabancı paranın borsada rayici yoksa, değerlemeye uygulanacak kur Maliye Bakanlığınca tespit olunur."

\section{Sonuç}

BOBi FRS' de büyük işletmeler için zorunlu, orta boy işletmeler için ihtiyari olan, ertelenmiş vergilerin raporlanması ve konsolide finansal tablo hazırlanma zorunluluğu KÜMi FRS'de yer almamaktadır. TFRS ve BOBi FRS olduğu gibi finansal tabloların hazırlanması, ihtiyaca uygunluk, gerçeğe uygun sunum, anlaşılabilirlik, karşılaştırılabilirlik ve zamanında sunum prensiplerinden yola çıkarak işletmenin sürekliliği, tahakkuk esası ve finansal tabloların sunumunda önemlilik ilkelerine dayanmaktadır. KÜMi FRS Taslağında BOBi FRS ve TFRS ile benzerlikler olduğu gibi, borçlanma maliyetlerinin oluştukları dönemde kar veya zarara yansıtılması, araştırma ve geliştirme giderlerinin tamamının giderleştirilmesi, varlıklarda değer düşüklüğü hesaplamasında dikkate alınacak değerlerle ilgili farklılıklar da bulunmaktadır. Bir varlığın değer düşüklüğüne uğradığına ilişkin bir göstergenin mevcut olması durumunda, BOBi FRS'de, ilgili varlığın defter değerinin, kullanım değeri ya da satış maliyetleri düşülmüş gerçeğe uygun değeri ile karşılaştırılması gerekiyorken, KÜMi FRS'de ilgili varlığın defter değeri ile satış maliyetleri düşülmüş gerçeğe uygun değeri karşılaştıııır. Kullanım değerinin hesaplanmasındaki zorluk, hesaplama için dikkate alınan değişkenlerin tespitindeki belirsizlikler nedeniyle KÜMi'ler tarafından karşılaştırma kriteri olarak sadece satış maliyetleri düşülmüş gerçeğe uygun değer kullanılmaktadır.

KÜMi FRS'de vergi uygulamalarımıza benzer şekilde, vadeli varlık alımlarında ve vadeli satışlarda (hasılatta) hiçbir zaman vade farkı ayrıştırılmaz, tüm alacak ve borçlar her raporlama dönemi sonunda reeskont işlemine tabi tutulur. Vergi uygulamaları ve MSUGT çerçevesinde dönem sonunda yapılan reeskont işlemlerinde de iç iskonto oranı kullanılmakta ancak bu uygulamada ertesi dönemlerin faiz tutarları dönem kar-zarar tablosunda gelir ve gider olarak raporlanmakta, ertesi dönemlerde ters kayıt ile iptal edilmektedir. Dolayısıyla döneme ait olmayan faiz gelir ve giderlerinin dönem kar zarar tablosunda kayıtlanması sakıncası bulunmaktadır.

Metin içinde ayrıntıları belirtilmiş olan KÜMi FRS Taslağı ve vergi uygulamalarımız arasındaki benzer düzenlemeler, vergi matrahı ile ticari karın yakınlaşmasını ve farkların daraltılmasını sağlamaktadır. Böylece TFRS'leri ve BOBi FRS'yi kullanmayan işletmeler de kolaylıkla uygulayabileceği KÜMi FRS ile ticari karını raporlayacağı bir finansal raporlama çerçevesine sahip olacaklardır.

Muhasebenin sosyal sorumluluğu, işletme ile ilgili taraflara doğru ve güvenilir, kararlarına dayanak olacak ve ihtiyaca uygun bilgiler sunmaktır. Bu nedenle işletmeler bilgi amaçlı finansal tablolar hazırlamalı, ticari muhasebe sonuçlarını raporlamalı ve daha sonra vergi mevzuatının gereklerine göre ticari kara ekleme ve çıkarmalar yaparak vergi matrahını hesaplamalıdır (Gücenme Gençoğlu, 2017: 21). Sonuç olarak ticari muhasebe anlayışının yaygınlaştırılması ve ülkemizde vergi muhasebesi anlayışından ticari muhasebe anlayışına geçilmesi için uygun ortam oluşabilmesinde KÜMi FRS ile önemli bir adım atılmaktadır. 


\section{Kaynaklar}

213 sayılı Vergi Usul Kanunu (1961), Resmi Gazete, 10703, 10 Ocak.

6102 sayılı Türk Ticaret Kanunu (2011), Resmi Gazete, 27846, 14 Şubat.

Bağırgan, M. K. (2019). Türkiye'de raporlama standartlarının gelişimi ve maddi duran varlıkların VUK, TMS/TFRS, BOBi FRS ve KÜMi FRS açısından değerlemesi. http://www.alomaliye.com/2019/11/18/maddi-duran-varliklarindegerlemesi (Erişim Tarihi: 7 Ekim 2019).

Büyük ve Orta Boy İşletmeler İçin Finansal Raporlama Standardı, 29 Temmuz 2017 tarihli ve 30138 ( Mükerrer) Sayılı Resmi Gazete.

Doğan, A. (2018). Büyük ve Orta Boy İşletmeler için Finansal Raporlama Standardı ile VUK/MSUGT karşılaştırması. Muhasebe ve Finansman Dergisi, Ekim, 115-132.

Gökçen, G., Öztürk, E., \& Güleç, Ö. F. ( 2019). KÜMi FRS seti taslağı, BOBi FRS Seti ve tam set TMS/TFRS'nin temel konular açısından karşılaştırılması. Finans Ekonomi ve Sosyal Araştırmalar Dergisi, 4(3), 413-430.

Gücenme Gençoğlu, Ü. (2017). Temel konularda BOBi FRS ve TMS/TFRS karşılaştırması. Muhasebe ve Finansman Dergisi, Ekim 2017, 1-24

Gücenme Gençoğlu, Ü. (2017). Ticari muhasebeye neden geçilmeli: Iktisadi gelişmede muhasebe ve denetimin önemi. KGK Muhasebe ve Denetim Sempozyumu, 27-28 Eylül 2017, İstanbul, Bildiriler Kitabı ISBN.978-605-8912-4-0.

Küçük ve Mikro Iş̧letmeler İçin Finansal Raporlama Standardı Taslağı. https://www.kgk.gov.tr/ (Erişim Tarihi: 12 Temmuz 2019).

Muhasebe Sistemi 1 Sıra Nolu Uygulama Genel Tebliği, 26/12/1992 tarihli ve 21447 Sayılı Mükerrer Resmi Gazete.

Sabuncu, B. (2018). Büyük ve Orta Boy İşletmeler İçin Finansal Raporlama Standardı ve Tekdüzen Muhasebe Sistemi açısından hasılatın ölçüm ve muhasebeleştirilmesinin incelenmesi. Muhasebe Bilim Dünyası Dergisi, 20(4), 738760. 
This Page Intentionally Left Blank 